\title{
Daniel, Rainolde, Demosthenes, and the Degree Speech of Shakespeare's Ulysses
}

CLIFFORD J. RONAN

Gayley, Muir, and the editors of the Variorum, Cambridge, and Arden Shakespeares carefully consider the numerous influences, direct and indirect, upon Ulysses' magnificent oration On Degree in Troilus and Cressida I.iii. ${ }^{1}$ Hints of the underlying premise of the speech - a threat to the universal binding power of the Cosmos - have been found in numerous Western writers, commencing with Homer, Plato, Ovid, and the apocalyptic authors of Holy Scripture. Shakespeare undoubtedly encountered the idea frequently in his reading and listening. But beyond his favourite Ovid, there can be scarcely more than two sources to which Shakespeare would be incontrovertibly exposed. One is Chaucer's Troilus and Criseyde, which would be Shakespeare's locus classicus for the Troilus story. There, in Boethian terminology, man is urged to live in harmony with that universal "bond of thynges" (III.1261), Love. ${ }^{2}$ Another indisputable source of On Degree is the official homily "Of Obedience" (1547), which Shakespeare would have heard as often as thirty times before the date of composition of this play (entered in the Stationers' Register early in 1603). " "Of Obedience" seems to be imitated and even echoed in several of Ulysses' phrases, particularly his "Take but degree away ... / And ... Discord" or "Chaos" "followes" (11. 115-33):

Euery degree of people, in their vocacion, callyng, \& office, hath appoynted to them, their duetie and ordre ... and euery one haue nede of other .... For wher ther is no right ordre, there reigneth all abuse, carnall libertie, enormitie, syn, \& babilonicall confusiō. Take awaye kynges, princes, rulers, magistrates, iudges, \& suche states of Gods ordre, no mā shall ride or go by the high waie vnrobbed ... and there must needes folow all mischief and vtter destruccio-....

("Of Obedience," Homilies, italics supplied)

Other works that On Degree has plausibly been said to echo include Cicero's Tusculan Disputations and, from more modern times, Elyot's Governor (1531) and Hooker's Ecclesiastical Polity (1593). It is here my purpose to suggest at least two additional verbal sources, neither of which seems ever to have been mentioned in connection with this play before. Both 
of these likely sources are concerned with rhetoric: Samuel Daniel's "Musophilus" (1599), a dialogue delineating functions of literature; and Richard Rainolde's Foundacion of Rhetorike (1563), a collection of original essays designed by the author to illustrate (for teachers, students, and general readers) a wide variety of rhetorical strategies. ${ }^{4}$ That Shakespeare should be alert to the ideas and locutions of Daniel would not be a surprising discovery, as he seems to have reacted to or borrowed from Daniel's treatment of Marcus Antonius and the War of the Roses. But if Shakespeare can be found contemplating Rainolde about 1600 , there may be something more worth noticing: the interestingly tight cluster of dates (1597-1603) when Shakespeare seems most to echo - and presumably thus to show a renewed interest in - the rhetorical textbooks of his age. ${ }^{5}$

The chief point of significant resemblance that I am proposing between Daniel's "Musophilus" and Ulysses' speech involves a hunting image and the apocalyptic phrase universal prey, which both authors use to describe the confusion and Armageddon that will occur if a great bond is missing Degree, for Shakespeare; Literary Excellence, for Daniel. According to Daniel, "Presumption" and "interiangling Ignorance" produce literature so ephemeral that poets cannot

hold out with the greatest might they may,

Against confusion, that hath all in chace,

To make of all, a vniuersall pray.

(“Musophilus," 11. 243-45)

Shakespeare seems to have substituted the word "Chaos" for "Confusion," and for the generalized image of a "chace," the particular image of the self-devouring "Wolfe":

Appetite (an vniuersall Wolfe[)]

Must make perforce an vniversall prey,

And last, eate vp himselfe.

This Chaos, when Degree is suffocate,

Followes the choaking.

(Tro. I.iii.127-33)

So fond does Shakespeare here become of the word universal that he uses it twice, applying it to the wolf as well as (with Daniel) to its primary prey.

Daniel, too, seems to have contributed to impulses, experienced by Shakespeare in many quarters, to speak of cosmic harmony (or its absence) in musical terminology. Hooker, it is often said, is the chief source for Ulysses' reference to the "Discord" that follows when the "string" of 
"Degree" is "taken[n] away" or "vn-tune[d]" (I.iii.115-16). And in a long passage on the threat of disorder in the Cosmos, Hooker does indeed make an explicit musical analogy:

See we not plainly that obedience of creatures unto the lawe of nature is the stay of the whole world? Notwithstanding with nature it commeth somtimes to passe as with arte. Let Phidias have rude and obstinate stuffe to carve, though his arte do that it should, his worke will lacke that bewtie which otherwise in fitter matter it might have had. He that striketh an instrument with skill, may cause notwithstanding a verie unpleasant sound, if the string whereon he striketh chaunce to be uncapable of harmonie.

(Ecclesiastical Polity, I.iii.2-3)

In Hooker the "string" "uncapable of harmonie" is implicitly ill-tuned, but only implicitly. In two interrelated passages in Daniel's "Musophilus," however, the author comes one step closer to speaking of a string that sounds out of tune. In Daniel we read of jarring poetic "discords" made by the "unhallowed string" - a term that may have helped inspire Shakespeare's reference to the "vn-tune[d] . . string" of degree-less "Discord":

so many so confusedly sing,

Whose diuers discords haue the Musicke mar'd,

And in contempt that mysterie doth bring,

That he must sing alowd that will be heard:

And the receiu'd opinion of the thing,

For some unhallowed string that vildely iar'd. ...

("Musophilus," 11.62-67; italics supplied)

The musical image of a Cosmos of poetry is repeated a hundred and fifty lines later in Daniel's reference to the "divers disagreeing cordes/ Of interiangling Ignorance" (11.234-36). Similarities of Daniel to Shakespeare in no way weaken the case for the dramatist's simultaneous use of Hooker here in Troilus (or for a use in such contemporary plays as Hamlet and Measure for Measure).$^{6}$ Instead, Hooker's influence would appear to reinforce, rather than surmount, that of Daniel in at least the musical imagery of these Ulyssean lines.

The opening of Hooker's First Book resembles Ulysses' speech not just in individual phrases but also in its broad, sweeping survey of an ordered, yet endangered, universe. Another evident resemblance between these two is shared also with such forebearers as Elyot's Governor, Rabelais' Gargantua, and the homily. This is only natural, because all five participate in an international tradition. What seems to have gone unremarked in the criticism of Troilus and Cressida, however, is that this tradition is a Renaissance one in the strictest sense: a revivifying of an ancient custom. When Hooker posits so eloquently a dissolution of our orderly universe- 
Now if nature should intermit her course, .. . if the frame of that heavenly arch erected over our heads should loosen and dissolve it selfe: if the ... seasons ... blend themselves by disordered and confused mixture, ... what would become of man himselfe...?

(Ecclesiastical Polity, I.iii.2)

- Hooker is, in fact, translating word for word (without acknowledgement) from a patristic source, Arnobius' Against the Pagans (I.2). ${ }^{7}$

A similar but more ancient and prestigious occurrence of this hallowed trope can be found in a popular speech often ascribed in the Renaissance to the great Demosthenes, the First Oration against Aristogiton.$^{8}$ There, too, we read of a hypothetical future disorder that will occur when some protective and unifying bond is loosed. In pseudo-Demosthenes, the verb is lu-ô ("luthentô" and "lethutai"), which means (and shares the same Indo-European root as) loosen. The word thus corresponds to "relaxata aut dissoluta" in Arnobius, "loosen and dissolve" in Hooker, and the "vntuned" or loosened string in Shakespeare (cf. "loose" 1. 124).

[If] the laws and the obedience that all men yield to the laws.... were done away with [luthentôn] and every man were given license to do as he liked, not only does the constitution vanish, but our life would not differ from that of the beasts of the field .... . For vice is . . . daring; . . . probity is . . . liable to come off second-best. Therefore ... juries ought to protect and strengthen the laws ... . If not, all is dissolved [lelutai], broken up, confounded, and the city becomes the prey of the most profligate and shameless.

(1st Aristogiton 20, 24-25)

After reading this speech about man's proclivity to political disease and psychological brutalization, we need not agree with the Victorian editor ${ }^{9}$ of Demosthenes, who, in silently citing a parallel with Troilus, seems to encourage a belief in Shakespeare's direct indebtedness. But this much is clear: pseudo-Demosthenes and Arnobius fall within the same subdivision of a classical tradition as do the Renaissance writers already cited.

Yet another such author, an Englishman who would have had to listen to the homily and could also have read Elyot, is Richard Rainolde, adapter and only Tudor translator of the most popular elementary composition text in Renaissance Europe, Aphthonius' Progymnasmata. ${ }^{10}$ Rainolde rewords and retitles this originally Hellenistic book, calling it the Foundacion of Rhetorike (1563). In his "Oration" "against thieues," Rainolde, unlike other adapters of the Progymnasmata, makes a point of mentioning and speaking highly of the pseudo-Demosthenean Aristogiton, which we have just examined. Moreover, Rainolde quotes from it and writes variations of its section on a hypothetical chaotic future. Rainolde's anticipations of Shakespeare's phraseology are in many regards as striking as Elyot's and the homilist's. 
Elyot, the anonymous author(s) of the homily, and Rainolde share with Shakespeare three speech patterns seen in no other purported source of the motif of universal dissolution. All four writings employ the phrase take away, place some universal bonding agent as direct object of take away, and speak in very similar language of the dire eventuality forthcoming. Specifically, each writer says that what "follow[s]" (homilist, Rainolde, Shakespeare) or "ensue[s]" (Elyot) is a "Chaos" (Elyot, Rainolde, Shakespeare) or "confusion" (homilist, Rainolde). Of all these three possible sources of the Ulysses' speech, Rainolde alone anticipates Shakespeare in dividing the phrase take away into its two halves, and in his precisely similar choice of both the words Chaos and follow(s):

Take but Degree away, vn-tune that string,

And hearke what Discord followes:

This Chaos, when Degree is suffocate,

Followes the choaking.

(Tro. I.iii.115-16, 132-33, italics supplied)

Take lawes a waie, all order of states faileth .... [B]othe lawes and the Prince, hane that honour and strength, that without them, a Chaos a confusion would followe....

(Foundacion, sig. I3r; italics supplied)

Other of Rainolde's phrases, pallid though they are in comparison with those in some alternate sources and in Shakespeare, seem also to anticipate Shakespeare and probably provide reinforcement for tendencies and devices he was already adopting under pressure of Platonic and other influences. (Book VIII of The Republic, for instance, describes psychology, sociology, and political science in terms drawn from medicine, music, and animal-lore, including wolf-lore. ${ }^{11}$ ) Specifically, Rainolde shares with Shakespeare the use of medical analogies in describing the Mesocosm, a conventional device present also in Elyot and the pseudoDemosthenes. ${ }^{12}$ Also, Rainolde, like Daniel, uses some musical imagery (e.g. "harmonie," "concorde," sig. I2r) and the word prey. Rainolde, however, is especially emphatic about the idea of beastly predation when the universal force is loosened. In a few consecutive pages of his long oration, Rainolde touches upon the bestiality motif a dozen times, of which the following is a fair sample:

Lawes ... kepe backe, the wilfull, rashe, and beastlie life of man, ... for ... of ill maners came good lawes, that is to saie, the wicked and beastlie life of man, their iniurius behauiour, sekyng to frame themselues from men to beastes .... If the labour and industrie of the godlie, should be alwaie a praie to $y$ wicked, and eche mannes violence and iniurious dealyng, his owne lawe, the beaste in his state, would bee lesse brutishe....

(Foundacion, sigs. I1 v-2v; italics supplied) 
In addition, Rainolde, unlike all the other purported sources, uses much imagery of the cutting down or uprooting of growing things. Disorders like earthquakes or tempests in the Mesocosm threaten, in Shakespeare, to "crack," "rend," and "deracinate" from its "fixure" the peaceful tree of state (11. 103-107). Such images are analogous to Rainolde's many remarks about criminal elements as "weedes" in need of being "plucked vp" (sig. I2r) or "cut of" where they "roo[t] out" virtue (sig. K2r). And lastly, in his use of contending abstractions, Rainolde is closer to Shakespeare than are Daniel, Hooker and other followers of Prudentius. Shakespeare's excitingly phrased psychomachia of "Force," "Iustice," "Power," "Strength," "Will," and "Appetite" (I.iii.120-28) seems to be anticipated in Rainolde's pseudo-Demosthenean passages, where this device is handled with a concentration and vibrancy approaching the dramatist's:

For, as Demosthenes the famous Orator of Athenes doeth saie. If that wicked
men cease not their violece... If dailie the heddes of wicked men, cease not to
subuerte lawes,... oppression and violence should bee lawe, and reason,
and wilfull luste would bee in place of reason, might, force, and power,
should ende the case. Wherefore, soche as no lawe, no order, nor reason, will
driue to liue as members in a common wealthe, to serue in their functio. Thei
are as Homere calleth theim, burdeins to the yearth....

(Foundacion, sign. I4r; italics supplied)

In both Rainolde and Shakespeare, it seems likely, the tune of these remarks is meant to seem Grecian or antique.

Shakespeare's resort to Rainolde may seem less credible than other of his borrowings. But Rainolde does write on rhetoric, a subject in which Shakespeare seems to have taken a remarkably clear professional interest in the years immediate before Troilus and Cressida (c. 1602). Puttenham is echoed, for instance, in Love's Labor's Lost (c. 1597); and Peacham, in Much Ado About Nothing, (c. 1598). Another rhetorical anthology like Rainolde's, Sylvain's Orator, is used in Merchant of Venice (c.1598).

Still, Rainolde is the most graceless and redundant of the four rhetoricians mentioned above, a writer whose prose is in the limping styles of a half century before the date of Troilus. Yet if young Shakespeare really had been, as rumored, "a Schoolmaster in the Countrey,"13 with a less thorough command of Latin and Greek than would be deemed appropriate, might he not have once been interested in this little teaching guide? After all, Rainolde comments also upon several subjects to which Shakespeare's writing interests brought him: Venus and Adonis, Helen, Hecuba, Menenius, Junius Brutus, Cassibelan, Caesar, Cato, Nero, Richard III, Henry VIII. Also Rainolde's pages resound with a salvo of Greek words and names: "Thesis," "Rhetorique," "Eidolopoeia," "Prosolopoeia," "Progimnasmata," "Democratia," and "tokos" (Greek for usury); and Thebes, 
Athens, Lacedaemon, Boeotia, Aphthonius, Aesop, Cadmus, Aristotle, Plato, Isocrates, Solon, Thucydides, Diogenes, Alexander, Lysimachus, Epaminondas. It is not inconceivable that Shakespeare would have turned, or returned, to this school text when he was contemplating formal rhetorics in the late $1590 \mathrm{~s}$. Then, remembering that Rainolde claimed to imitate Demosthenes at some length, Shakespeare might have come back to make specific borrowings when he needed to devise an antique speech for the greatest of Homeric orators. Perhaps Rainolde's version of the famous Demosthenes looked "Greek" enough to the dramatist. And if he checked the Greek original or one of the Latin translations, ${ }^{14}$ Shakespeare would have found that Rainolde is faithful to the ancient rhetorical topos of the threatened return of chaos - a tradition whose classical associations and connotations were probably as well known to Shakespeare and his audience as they were to Elyot, Cranmer and associates, Hooker, and Daniel.

\section{Southwest Texas State University}

Notes

1 Shakespeare citations are to the New Variorum Troilus and Cressida, Harold N. Hillebrand and T. W. Baldwin, edd. (Philadelphia: Lippincott, 1953). Besides the above (pp. 51-59, 389-410), the chief extended discussions of the sources of On Degree include Charles Mills Gayley, Shakespeare and the Founders of Liberty in America (New York: Macmillan, 1917) pp. 162-90, 234-59; Alice Walker, ed., Troilus and Cressida (Cambridge: Cambridge University Press, 1969), p. 153; Kenneth Palmer, ed., Troilus and Cressida (London: Methuen, 1982), pp.320-22; and Kenneth Muir, The Sources of Shakespeare's Plays (New York: Yale University Press, 1978), pp. 151-57. It should be noted that this last work, a standard authority, erroneously states that Hooker formulates Shakespeare's phrase "Degrees in Schooles" (I.iii.110). Hillebrand, p. 391 , on the contrary, follows Gayley and quite rightly stresses that Hooker could have provided the "figure" of academic ranks; nowhere does the phrase degrees in schools occur in Hooker, even though a discussion of such degrees is to be found in Hooker's Preface. The Hooker passage in question is some 8,000 words, or 18 folio pages, prior to the passages on the Cosmos in Book I, the portion of Hooker with the best claim to underlie Ulysses' speech. Below, unless otherwise specified, Richard Hooker is cited in Of the Laws of Ecclesiastical Polity, Vol. I, ed. Georges Edelen, Folger Library Edition (Cambridge: Belknap Press of Harvard University Press, 1977).

2 Chaucer is cited in F. N. Robinson's ed. of The Works, 2nd ed. (Boston: Houghton, 1957); see also the binding "cheyne of love" in Knight's Tale (a source of MND), 11.2988ff.

3 In 1602, Shakespeare (b. 1564) would have been a churchgoer for some 30 years. Alfred Hart, Shakespeare and the Homilies (Melbourne: Melbourne University Press, 1934), p. 73, reminds us that attendance was compulsory in Tudor parishes and that "Of Obedience" would be read annually. A recent writer on this subject, Professor Ronald B. Bond of the University of Calgary, has communicated to me privately his opinion that this crucial homily would have been read more than once a year. Bond, too, believes that the "controlling hand" in "Of Obedience" is Cranmer's; see Bond's "Cranmer and the Controversy Surrounding Publication of Certayne Sermons or Homilies (1547)," Renaissance and Reformation, 12 (1976), 28-35, especially 30. My citation of the Tudor "Of Obedience" is from the readily available excerpts in the Variorum Troilus, though I have also consulted a full text in Certaine Sermons or homilies . . . , intro., Mary Ellen Rickey and Thomas B. Stroup (1623; Gainesville: Scholars' Facsim., 1968).

4 The Daniel and Rainolde citations are from Samuel Daniel, Musophilus, ed. Raymond Himelick (West Lafayette, IN: Purdue University Studies, 1965) and Richard Rainolde, The Foundation of Rhetorike, The English Experience, no. 91 (1563; facsim. rpt. Amsterdam: Da Capo, 1969). 
5 For Shakespeare's use of formal rhetorics, see below; Sister Miriam Joseph, Shakespeare's Use of the Arts of Language (New York: Columbia University Press, 1947) pp. 44, 113; and Kenneth Muir, "Shakespeare and Rhetoric," Shakespeare-Jahrbuch (Heidelberg) 90 (1954), 49-68. Troilus is usually assigned to 1601-02. Commenting on the likely use of rhetorical works in, respectively, Merchant of Venice (1596-97), Much Ado (1598-99), and Love's Labor's Lost (1594-97), Muir believes that Shakespeare "seems to have read Pyott's translation of The Orator, Peacham's Garden of Eloquence, and Puttenham's Arte of English Poesie" (Muir, "Rhetoric," 53).

6 Gayley (pp. 187-89) argues for an especially strong influence of Hooker on Hamlet. To me, it seems that the lines in Measure for Measure on glass, apes, heaven, and angels(II.ii) could involve Shakespeare's reading Hooker's passage on the order and degree of angels. Hooker's angels are internally ranked and given to searching for divine reflections in themselves and man; they are filled with a God-like love "unto the children of men; in the countenance of whose nature looking downeward they behold themselves beneath themselves, even as upwarde in God, beneath whom themselves are, they see that creature which is no where but in themselves and us resembled" (I.iv.1).

7 For a convenient look at the Arnobius text, see Christopher Morris' notes to his Everyman ed., Richard Hooker, Of the Laws of Ecclesiastical Polity, 2 vols. (London: Dent, 1907), I, 157.

8 English and Greek citations of the 1 st Aristogiton are from the J. Vince ed., Demosthenes: Against Meidias, ... Aristogeiton, Loeb Classical Library (Cambridge, MA: Harvard University Press, 1935). I have, in addition, consulted various sixteenth-century Greek editions and one of the Latin translations at which Shakespeare could have glanced (Philip Melanchthon, tr., Contra Aristogiton ..., Hague, 1527).

9 Charles Rann Kennedy, ed., The Orations of Demosthenes, Vol. IV, Bohn's Classical Library (1888; London: George Bell, 1901), p. 61, n. 1, quotes Tro. I.iii. 109-30 with only the simple and enigmatic introductory comment "compare...."

10 F. R. Johnson provides a useful summary of the reputation of Rainolde and the popularity of Aphthonius and his Latin imitators; see Johnson's introduction to his facsimile of Foundacion of Rhetorike (New York: Scholars' Facsim., 1945). For the schoolroom use of Aphthonius, see T. W. Baldwin, William Shakespeare's "Small Latine \& Lesse Greek," 2 vols. (Urbana: Illinois University Press, 1944), II, 288 et passim. Marion Trousdale, Shakespeare and the Rhetoricians (Chapel Hill: University of North Carolina Press, 1981), pp. 3-38, makes an interesting case for Rainolde as an important specimen of a class of rhetoricians whom Shakespeare may almost everywhere be imitating.

11 Cf. James Holly Hanford, “A Platonic Passage in Shakespeare's Troilus and Cressida," Studies in Philology, 13 (1916), 100-09.

12 Rainolde wants magistrates to rid their country of "yll humors" and "ill bloode" (sig. 12v) when the land is "plagued" with "pestiferous doinges" (sig. 13r). For this imagery of the diseased corpus politicum there are Greek antecedents: in Plato (Relublic 564B), who speaks of a country's disease (nosêma); and in pseudo-Demosthenes, who terms criminals incurable (aniatos) and cancerous. (See the P. Shorey ed., The Republic, 2 vols. Loeb Library [London: Heinemann, 1930-35].) But since Elyot anticipates Shakespeare's use of the word "med'cinable," perhaps the early Tudor Englishman is as responsible as any of the other authors for Shakespeare's talk of the Greek enterprise as "pale" and "sicke" of "Feauer" and "Plagues." See Sir Thomas Elyot, The Boke Named the Gouernour, 2 vols., ed. Henry Herbert Stephen Croft (London: Kegan, 1883), I, 5.

13 The written source is John Aubrey, quoting Christopher Beeston, son of one of Shakespeare's colleagues in the King's Men. Reasons for accepting Aubrey's account are well argued by, among others, Baldwin in his Small Latine II, 36 et passim.

14 Baldwin, Small Latine II, 650 and 661 states that proof is lacking for Shakespeare's use of any work ascribed to Demosthenes. At least until such proof may be forthcoming, Shakespeare's dependence on the second-hand Athenian classicism of Rainolde will continue to be most probable. 